\title{
Heavy Metal Pollution Associated with an Abandoned Lead-Zinc Mine in the Kirki Region, NE Greece
}

\author{
Christos Nikolaidis - Ilias Zafiriadis • \\ Vasileios Mathioudakis • Theodore Constantinidis
}

Received: 27 February 2010/ Accepted: 9 July 2010

(C) Springer Science+Business Media, LLC 2010

\begin{abstract}
The "Agios Philippos" mine in the Kirki region (NE Greece) has been abandoned in 1998 after half a century of ore exploration without a reclamation or remediation plan. This article aims at elucidating the potential environmental risks associated with this site by quantifying pollution in tailing basins, stream waters, stream sediments and agricultural fields. Concentrations of heavy metals in the abandoned mine tailings reached $12,567 \mathrm{mg} / \mathrm{kg}$ for $\mathrm{Pb}, 22,292 \mathrm{mg} / \mathrm{kg}$ for $\mathrm{Zn}, 174 \mathrm{mg} / \mathrm{kg}$ for $\mathrm{Cd}$ and $241 \mathrm{mg} / \mathrm{kg}$ for As. The geoaccumulation index and enrichment factor for these metals were indicative of extremely high contamination $\left(I_{\text {geo }}>5\right)$ and extremely high enrichment $(\mathrm{EF}>40)$, respectively. Stream waters in the proximity of the mine had an acidic $\mathrm{pH}$ equal to 5.96 and a high sulfate content $\left(\mathrm{SO}_{4}^{-2}=545.5 \mathrm{mg} / \mathrm{L}\right)$, whereas concentrations of $\mathrm{Mn}, \mathrm{Zn}$ and $\mathrm{Cd}$ reached $2,399 \mu \mathrm{g} / \mathrm{L}$, $7,681 \mu \mathrm{g} / \mathrm{L}$ and $11.2 \mu \mathrm{g} / \mathrm{L}$. High $I_{\text {geo }}$ and EF values for Cd, $\mathrm{Zn}$ and As in stream sediments indicates that surface water pollution has a historic background, which is typically associated with acid mine drainage. Agricultural fields in the proximity of the mine exhibited high $I_{\text {geo }}$ and EF values, which were in decreasing order $\mathrm{Cd}>\mathrm{Pb}>\mathrm{Zn}>$ As. These findings urge for an immediate remediation action of the afflicted area.
\end{abstract}

C. Nikolaidis $(\bowtie) \cdot$ T. Constantinidis

Laboratory of Hygiene and Environmental Protection,

Medical School, Democritus University of Thrace, Dragana,

Alexandroupolis 68100, Greece

e-mail: cnikolae@med.duth.gr

I. Zafiriadis · V. Mathioudakis

Department of Environmental Engineering, Democritus

University of Thrace, Vas. Sofias 12, 67100 Xanthi, Greece
Keywords Abandoned mine - Heavy metal . Geochemical index $\cdot$ Enrichment factor

The first metallurgical exploration of the "Agios Philippos" mine in the Kirki region (NE Greece) began late in the nineteenth century. A small-scale underground exploitation took place between 1932 and 1934 and resulted in the production of approximately 20,000 tons of ore. During World War II the German company "Thraziche Bergwerke" installed a floatation plant with an 80 ton/day capacity and in the following years the Greek State and privately-owned companies took over the operation. Between 1976 and 1997 some 200,000 tons of sulfide ore have been extracted and processed. Ever since, the mine has been abandoned without any reclamation and/or rehabilitation of the afflicted area.

Around the abandoned mine there are five tailings basins. No drainage ditches, containment impoundments or surface land cover has been used to control the leaching of wastes (Triantafyllidis et al. 2007; Loupasakis and Konstantopoulou 2010). The dispersal of mining waste has been facilitated by surface runoff during rainfall, wind action and draining effluent. As a result substantial pollution of surface water, sediments and agricultural soil has taken place. In order to determine the degree and extend of heavy metal contamination associated with this site, samples from mine tailings, agricultural soils, stream water and sediments have been collected and analyzed.

\section{Materials and Methods}

Six surface water samples were collected along the course of the river (Fig. 1). Each sample consisted of two 
Fig. 1 Location of the study area and map of the Agios Philippos mine
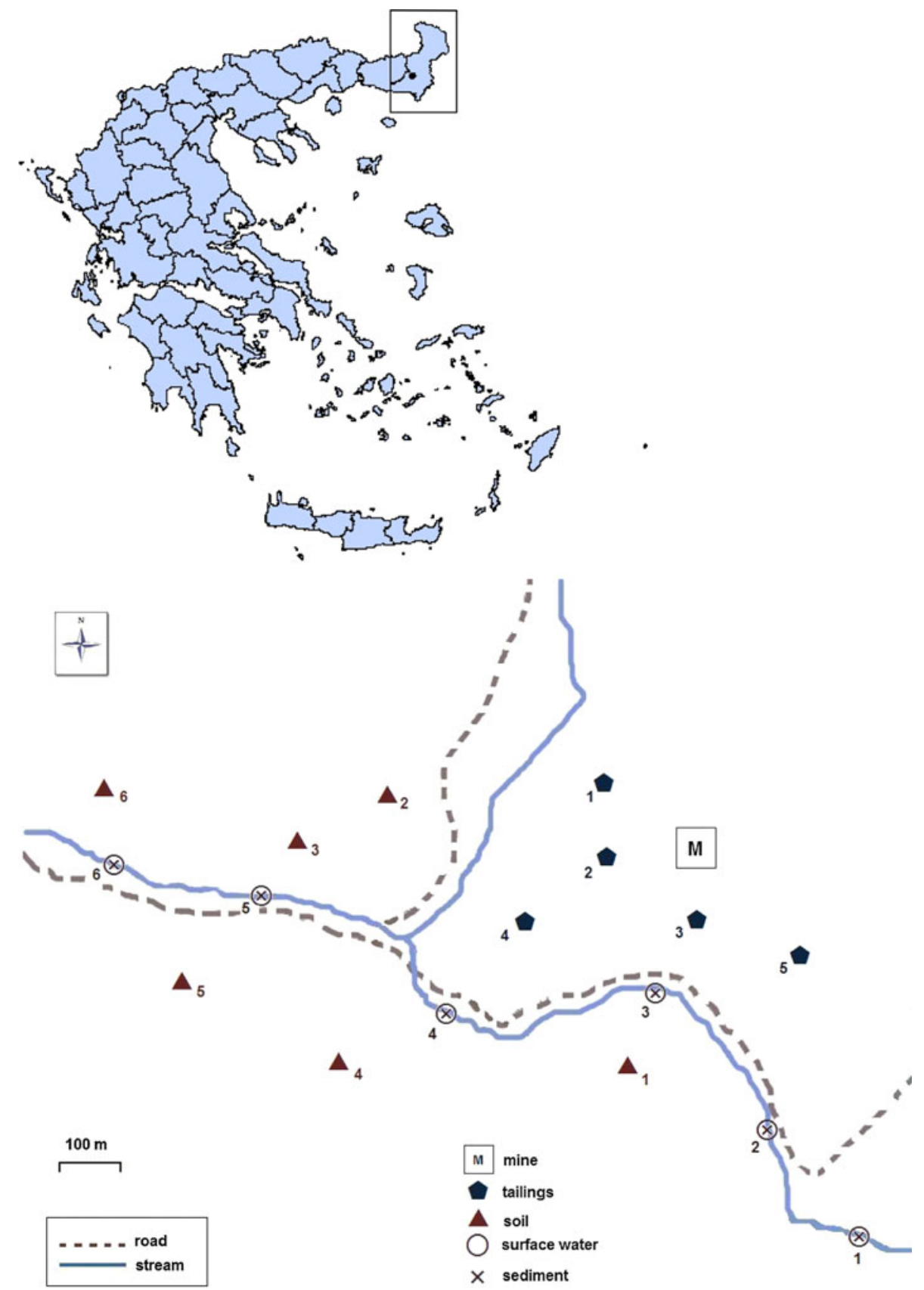

subsamples, one of which was acidified with $\mathrm{HNO}_{3}$ to $\mathrm{pH}<2$ for metal analysis and the other was left unacidified for anion analysis. Electrical conductivity, $\mathrm{pH}$ and temperature were measured in the field. Five soil samples were collected from tailings basins scattered around the mine. Moreover, six soil samples were collected from agricultural fields in the proximity of the mine. Sediment samples were collected at exactly the same locations as surface water samples, in order to investigate the effect of acid mine drainage (Fig. 1). All solid samples consisted of about $200 \mathrm{~g}$ each and they were collected at a depth of $0-20 \mathrm{~cm}$. Soil and sediment samples were dried at $70^{\circ} \mathrm{C}$ for
2 days and sieved through a $2 \mathrm{~mm}$ polyethylene sieve. They were then ground in an agate grinder until fine particles $(<200 \mu \mathrm{m})$ and aliquots of $0.25 \mathrm{~g}$ were digested with $1 \mathrm{~mL} \mathrm{HNO}_{3}$ and $3 \mathrm{~mL} \mathrm{HCl}$ (aqua regia). The solution was heated to $70^{\circ} \mathrm{C}$ and then deionized water was added to a final volume of $10 \mathrm{~mL}$. Analytical determination of trace metal was carried out by Graphite Furnace Absorption Spectroscopy (Perkin Elmer AAnalyst 800). Arsenic was determined by Hydride Generation-Absorption Spectroscopy (Perkin Elmer AAnalyst 200) and anions were measured by Ion Chromatography (Dionex ICS-1000). For quality control, reagent blanks, duplicates and soil 
international reference material (NIST 2709) were incorporated in the analysis to detect any contamination in the analytical materials and to assess precision and bias in the method. The analytical results showed no sign of contamination in the materials used. The recovery rates were in agreement with the certified concentrations $(98 \%$ for $\mathrm{Cu}$, $101 \%$ for $\mathrm{Zn}, 104 \%$ for $\mathrm{Pb}, 92 \%$ for As, $110 \%$ for $\mathrm{Cd}$ and $90 \%$ for $\mathrm{Mn}$ ).

\section{Results and Discussion}

The mine is located in a mountainous area, shaped by narrow valleys and springs that form a complex hydrological network of approximately $20 \mathrm{~km}^{2}$. Around the abandoned mine there are five tailings basins composed of largely conglomerate rocks with loose millet-seed sandstone texture, which exhibit weak water-tightness and are highly susceptible to erosion (Loupasakis and Konstantopoulou 2010). This is clearly evident in the perimeter, where ruptures and slidings of natural barriers are observed. The origin of the metalliferous ore in the Kirki region is sulphuric and pollymetalic. The mineralogy is classified as hydrothermal replacement type and mostly contains pyrite, sphalerite, galena, wurtzite and jordanite, where as secondary ore comprises of smaller amounts of tennantite, kasterite, cosalite and seligmanite (Triantafyllidis et al. 2007). This geochemical setting predisposes for acid mine drainage leading to heavy metal mobilization to the aquatic environment.

Six surface water samples were collected from the river traversing the mine area in the direction of flow from East to West. The results of the chemical analyses are presented in Table 1. A deterioration of quality characteristics, in terms of heavy metal content, ion concentration and $\mathrm{pH}$ was observed in samples 2-5. Sulfate content in these samples ranged between 256 and $545.5 \mathrm{mg} / \mathrm{L}$ exceeding $\mathrm{EU}$ drinking water guidelines. Accordingly, the $\mathrm{pH}$ of samples 2-5 appeared slightly acidic, ranging between 5.96 and 6.99. These findings are indicative of acid mine drainage originating from the mine's abandoned tailings basins (Olías et al. 2005; Chon and Hwang 2000). Samples 3 and 4 where particularly enriched in $\mathrm{Mn}, \mathrm{Zn}$ and $\mathrm{Cd}$. On the other hand, surface water concentrations of $\mathrm{As}, \mathrm{Pb}, \mathrm{Ni}$, $\mathrm{Cr}, \mathrm{Cu}$ and $\mathrm{Fe}$ were in compliance with the EU directive 98/83/EC.

Mine wastes from tailings basins and soil samples from agricultural fields were also collected from the study area to evaluate the distribution of metals within the surrounding environment (Table 2). Extremely high concentrations of $\mathrm{Zn}(22,292 \mathrm{mg} / \mathrm{kg}), \mathrm{Pb}(12,567 \mathrm{mg} / \mathrm{kg}), \mathrm{Cd}(174.1 \mathrm{mg} / \mathrm{kg})$, $\mathrm{Cu}(1,201 \mathrm{mg} / \mathrm{kg})$ and $\mathrm{As}(369.8 \mathrm{mg} / \mathrm{kg})$ were recorded in tailings samples (T1-T5). The heavy metal content of agricultural soils was greater in samples A1-A3 that were closer to the mine portal $(300-600 \mathrm{~m})$, than in samples A4-A6, which were located further away $(650-950 \mathrm{~m})$. This indicates that the pollution of soils is directly related to the mining activities. In order to address the effect of acid mine drainage on the river system, six sediments samples (S1-S6) were collected and analyzed. The highest concentrations of $\mathrm{Mn}, \mathrm{Zn}, \mathrm{Pb}, \mathrm{Cd}$ and As were recorded in samples $\mathrm{S} 3$ and $\mathrm{S} 4$. This suggests that the river has received a significant amount of contaminants in the course of time.

The effects of mining activities were further assessed using the geoaccumulation index $\left(I_{\mathrm{geo}}\right)$ and enrichment factor (EF) speciation. Igeo was introduced by Müller

Table 1 Chemical analyses of water samples

\begin{tabular}{|c|c|c|c|c|c|c|c|}
\hline & 1 & 2 & 3 & 4 & 5 & 6 & $\begin{array}{l}\text { EU drinking } \\
\text { water standards* }\end{array}$ \\
\hline $\mathrm{pH}$ & 7.12 & 6.99 & 5.96 & 6.16 & 6,75 & 7.01 & $6.5-9.5$ \\
\hline $\mathrm{EC} \mu \mathrm{S} / \mathrm{cm}$ & 719 & 801 & 1,094 & 1,038 & 853 & 813 & 2,500 \\
\hline $\mathrm{Ca} \mathrm{mg} / \mathrm{L}$ & 113.5 & 111 & 123.8 & 151.8 & 151.3 & 134.2 & $* *$ \\
\hline $\mathrm{SO}_{4} \mathrm{mg} / \mathrm{L}$ & 138 & 256 & 338.8 & 545.5 & 530.8 & 212 & 250 \\
\hline $\mathrm{Fe} \mu \mathrm{g} / \mathrm{L}$ & 80 & 96 & 184 & 192 & 153 & 73 & 250 \\
\hline $\mathrm{Cu} \mu \mathrm{g} / \mathrm{L}$ & 25 & 31 & 42 & 40 & 53 & 13 & 2,000 \\
\hline $\mathrm{Mn} \mu \mathrm{g} / \mathrm{L}$ & 22.5 & 87.1 & $2,398.5$ & $1,596.3$ & 543.5 & 54 & 50 \\
\hline $\mathrm{Zn} \mu \mathrm{g} / \mathrm{L}$ & 565.7 & 396 & 7,681 & $3,873.8$ & 876.3 & 422.1 & $* *$ \\
\hline $\mathrm{Cr} \mu \mathrm{g} / \mathrm{L}$ & 0.7 & 1.2 & 1.3 & 0.9 & 1.4 & 1.1 & 50 \\
\hline $\mathrm{Ni} \mu \mathrm{g} / \mathrm{L}$ & 0.4 & 0.7 & 0.5 & 1.2 & 0.9 & 1.0 & 20 \\
\hline $\mathrm{Pb} \mu \mathrm{g} / \mathrm{L}$ & 1.2 & 1.4 & 1.5 & 2.9 & 2.7 & 1.6 & 10 \\
\hline $\mathrm{Cd} \mu \mathrm{g} / \mathrm{L}$ & 0.2 & 0.36 & 11.2 & 8.4 & 3.1 & 1.2 & 5 \\
\hline As $\mu \mathrm{g} / \mathrm{L}$ & n.d. $* * *$ & n.d. $* * *$ & n.d. $* * *$ & 0.18 & 0.1 & n.d. $* * *$ & 10 \\
\hline
\end{tabular}

* Council Directive 98/83/EC, ** not specified, *** not detected 
Table 2 Chemical analyses of mine tailings (T1-5), agricultural soils (A1-6) and stream sediments (S1-6)

\begin{tabular}{llllllll}
\hline $\mathrm{mg} / \mathrm{kg}$ & $\mathrm{Mn}$ & $\mathrm{Fe}$ & $\mathrm{Zn}$ & $\mathrm{Cu}$ & $\mathrm{Pb}$ & $\mathrm{Cd}$ & $\mathrm{As}$ \\
\hline $\mathrm{T} 1$ & 263.9 & 26,767 & 4,243 & 151.5 & 3,162 & 32.2 & 85.5 \\
$\mathrm{~T} 2$ & 231.5 & 33,103 & 2,504 & 604.5 & 12,567 & 15.4 & 241.1 \\
$\mathrm{~T} 3$ & 493.8 & 23,231 & 22,292 & 1,201 & 7,937 & 174.1 & 369.8 \\
$\mathrm{~T} 4$ & 396.4 & 20,198 & 14,064 & 572.3 & 4,449 & 75.4 & 151.9 \\
$\mathrm{~T} 5$ & 878.3 & 25,946 & 19,463 & 947.8 & 8,933 & 143.4 & 303.3 \\
$\mathrm{~A} 1$ & 450.5 & 36,551 & 345.1 & 28.3 & 80.4 & 3.2 & 8.9 \\
$\mathrm{~A} 2$ & 878.3 & 27,586 & 474 & 42.7 & 219 & 5.8 & 14.1 \\
$\mathrm{~A} 3$ & 1,212 & 22,517 & 256.3 & 37.7 & 195.4 & 2 & 11.4 \\
$\mathrm{~A} 4$ & 511.2 & 26,324 & 103.6 & 12.8 & 28.5 & 3.1 & 7.1 \\
$\mathrm{~A} 5$ & 607.4 & 22,455 & 56.9 & 17.4 & 36.3 & 1.2 & 4.7 \\
$\mathrm{~A} 6$ & 342.1 & 30,101 & 47.4 & 14.9 & 31 & 0.9 & 5.4 \\
$\mathrm{~S} 1$ & 453.2 & 22,000 & 101.2 & 26.7 & 39.7 & 0.7 & 8.35 \\
$\mathrm{~S} 2$ & 901 & 24,211 & 178.7 & 14.9 & 45.8 & 1.2 & 14.1 \\
$\mathrm{~S} 3$ & 5,180 & 27,543 & 3,986 & 58.6 & 302 & 34.7 & 24.6 \\
$\mathrm{~S} 4$ & 4,054 & 30,212 & 3,918 & 130.7 & 279.2 & 26.9 & 22.6 \\
$\mathrm{~S} 5$ & 2,469 & 21,546 & 2,750 & 26.7 & 110.4 & 16.4 & 18.3 \\
S6 & 1,204 & 19,321 & 1,996 & 42.6 & 96.8 & 17.2 & 7.5 \\
\hline
\end{tabular}

Table 3 Geoaccumulation index according to Müller (1969)

\begin{tabular}{lll}
\hline Class & Value & Soil or sediment quality \\
\hline 0 & $I_{\text {geo }} \leq 0$ & Uncontaminated \\
1 & $0<I_{\text {geo }}<1$ & Uncontaminated to moderately contaminated \\
2 & $1<I_{\text {geo }}<2$ & Moderately contaminated \\
3 & $2<I_{\text {geo }}<3$ & Moderately to heavily contaminated \\
4 & $3<I_{\text {geo }}<4$ & Heavily contaminated \\
5 & $4<I_{\text {geo }}<5$ & Heavily to extremely contaminated \\
6 & $5<I_{\text {geo }}$ & Extremely contaminated \\
\hline
\end{tabular}

(1969) and enables the assessment of contamination by comparing current and pre-industrial concentrations of heavy metals. This index is computed by the following equation $I_{\text {geo }}=\log _{2} C_{\mathrm{n}} / 1.5 B_{\mathrm{n}}$, where $C_{\mathrm{n}}$ is the concentration of the element in the enriched samples and $B_{\mathrm{n}}$ is the background concentration of the element in the Earth's crust, according to Taylor and McLennan (1995). The factor 1.5 is used to address possible variations due to lithogenic effects (Stoffers et al. 1986). Müller (1969) has suggested 6 descriptive classes of geoaccumulation index (Table 3).

Heavy metal geoaccumulation in tailings samples shows extreme contamination with $\mathrm{Cd}, \mathrm{Pb}, \mathrm{As}$ and $\mathrm{Zn}$ (Table 4). Agricultural soils, however, exhibit various levels of geoaccumulation for different metals. Sample A1, which is located closer to the mine portal appears to be the most heavily contaminated. Geoaccumulation of $\mathrm{Pb}$ and $\mathrm{Zn}$ was very low in samples A5-A6, whereas As was moderately geoaccumulated and Cd heavily. Stream sediments S4 and
Table 4 Geoaccumulation index for mine tailings (T1-5), agricultural soils (A1-6) and stream sediments (S1-6)

\begin{tabular}{lrrrrrr}
\hline & \multicolumn{1}{c}{$\mathrm{Cu}$} & \multicolumn{1}{c}{$\mathrm{Mn}$} & \multicolumn{1}{c}{$\mathrm{Zn}$} & $\mathrm{Pb}$ & $\mathrm{Cd}$ & $\mathrm{As}$ \\
\hline $\mathrm{T} 1$ & 2.0 & -1.8 & 5.3 & 6.7 & 7.8 & 5.3 \\
$\mathrm{~T} 2$ & 4.0 & -2.0 & 4.6 & 8.7 & 6.7 & 6.7 \\
$\mathrm{~T} 3$ & 5.0 & -0.9 & 7.7 & 8.1 & 10.2 & 7.4 \\
$\mathrm{~T} 4$ & 3.9 & -1.2 & 7.1 & 7.2 & 9.0 & 6.1 \\
$\mathrm{~T} 5$ & 4.7 & 0 & 7.5 & 8.2 & 9.9 & 7.1 \\
$\mathrm{~A} 1$ & 4.7 & 0 & 7.5 & 8.2 & 9.9 & 7.1 \\
$\mathrm{~A} 2$ & -0.4 & -1 & 1.7 & 1.4 & 4.4 & 2.0 \\
$\mathrm{~A} 3$ & 0.2 & 0.0 & 2.2 & 2.9 & 5.3 & 2.7 \\
$\mathrm{~A} 4$ & 0.0 & 0.4 & 1.3 & 2.7 & 3.8 & 2.3 \\
$\mathrm{~A} 5$ & -1.6 & -0.8 & 0 & -0.1 & 4.4 & 1.7 \\
$\mathrm{~A} 6$ & -1.1 & -0.6 & -0.9 & 0.3 & 3.0 & 1.1 \\
$\mathrm{~S} 1$ & -1.3 & -1.4 & -1.2 & 0.1 & 2.6 & 1.3 \\
$\mathrm{~S} 2$ & -0.5 & -1.0 & -0.1 & 0.4 & 2.3 & 1.9 \\
S3 & -1.3 & 0.0 & 0.8 & 0.6 & 3.0 & 2.7 \\
$\mathrm{~S} 4$ & 0.6 & -0.8 & 5.2 & 3.3 & 7.9 & 3.5 \\
S5 & 1.8 & 2.2 & 5.2 & 3.2 & 7.5 & 3.3 \\
S6 & -0.5 & 1.5 & 1.4 & 1.9 & 6.8 & 3.0 \\
\hline
\end{tabular}

S5 were mostly affected. $I_{\text {geo }}$ values for $\mathrm{Cd}$ and $\mathrm{Zn}$, as well as $\mathrm{Pb}$ and $\mathrm{As}$, were indicative of "extreme" and "heavy" contamination, respectively.

The enrichment factor was calculated using the formula $\mathrm{EF}=\left(C_{\mathrm{n}} / C_{\text {ref }}\right)_{\text {sample }} /\left(B_{\mathrm{n}} / B_{\text {ref }}\right)$ originally introduced by Buat-Menard and Chesselet (1979), where $C_{\mathrm{n}}$ (sample) is the content of the examined element, $C_{\text {ref }}$ (sample) is the content of the reference element, $B_{\mathrm{n}}$ is the background value of the examined element and $B_{\text {ref }}$ (sample) is the background value of the reference element. In this study, Fe was used as the reference element at a crustal abundance value of $35,000 \mathrm{mg} / \mathrm{kg}$ (Taylor and McLennan 1995). Sutherland (2000) has proposed five contamination categories for EF: $<2=$ minimal enrichment, $2-5=$ moderate enrichment, $5-20=$ significant enrichment, $20-40=$ very highly enriched, $>40=$ extremely highly enriched. The $\mathrm{EF}$ values for $\mathrm{Zn}, \mathrm{Pb}, \mathrm{Cd}$ and $\mathrm{As}$ in the tailings samples show extremely high enrichment (Table 5). Cadmium is the most polluting element in agricultural soils (A1-A5) with EF values ranging between 10.7 and 42.1. The elements $\mathrm{Zn}, \mathrm{Pb}$ and As show significant enrichment only in samples A1-A3 and moderate enrichment in samples A4A6. As regards stream sediments, cadmium appeared to be "extremely highly" enriched in all of the samples (S1-S6) with an EF value ranging between 271.8 and 2,676.5. Zinc was "extremely" enriched in samples S3, S4 and S6 and was "significantly" enriched in samples S3 and S4. Finally, arsenic showed "significant" enrichment in samples S2S5, which is indicative of the acid mine drainage hypothesis discussed earlier. 
Table 5 Enrichment factor in mine tailings (T1-5), agricultural soils (A1-6) and stream sediments (S1-6)

\begin{tabular}{lrrrrrr}
\hline & $\mathrm{Cu}$ & $\mathrm{Mn}$ & \multicolumn{1}{c}{$\mathrm{Zn}$} & \multicolumn{1}{c}{$\mathrm{Pb}$} & \multicolumn{1}{c}{$\mathrm{Cd}$} & \multicolumn{1}{c}{ As } \\
\hline $\mathrm{T} 1$ & 7.9 & 0.6 & 78.1 & 206.7 & $2,676.5$ & 74.5 \\
$\mathrm{~T} 2$ & 25.6 & 0.4 & 37.3 & 664.4 & $1,333.2$ & 169.9 \\
$\mathrm{~T} 3$ & 72.4 & 1.2 & 473.0 & 597.9 & $1,973.9$ & 371.4 \\
$\mathrm{~T} 4$ & 39.7 & 1.1 & 343.2 & 385.5 & 31.3 & 175.5 \\
$\mathrm{~T} 5$ & 51.1 & 2.0 & 369.8 & 602.5 & 75.1 & 272.8 \\
$\mathrm{~A} 1$ & 1.1 & 0.7 & 4.7 & 3.8 & 31.7 & 5.7 \\
$\mathrm{~A} 2$ & 2.2 & 1.9 & 8.5 & 13.9 & 42.1 & 11.9 \\
$\mathrm{~A} 3$ & 2.3 & 3.1 & 5.6 & 15.2 & 19.1 & 11.8 \\
$\mathrm{~A} 4$ & 0.7 & 1.1 & 1.9 & 1.9 & 10.7 & 6.3 \\
$\mathrm{~A} 5$ & 1.1 & 1.6 & 1.2 & 2.8 & 11.4 & 4.9 \\
$\mathrm{~A} 6$ & 0.7 & 0.7 & 0.8 & 1.8 & 17.7 & 4.2 \\
S1 & 1.7 & 1.2 & 2.3 & 3.2 & 449.9 & 8.9 \\
S2 & 0.9 & 2.2 & 3.6 & 3.3 & 318.0 & 13.6 \\
S3 & 3.0 & 1.1 & 71.3 & 19.2 & 271.8 & 20.8 \\
S4 & 6.1 & 7.8 & 63.9 & 16.2 & 317.9 & 17.5 \\
S5 & 1.7 & 6.7 & 6.3 & 9.0 & $2,676.5$ & 19.8 \\
S6 & 3.1 & 3.6 & 50.9 & 8.8 & $1,333.2$ & 9.1 \\
\hline
\end{tabular}

Hakanson (1980) proposed an overall indicator of contamination based on integrative data. This method is based on the calculation of contamination factor $\left(C_{\mathrm{f}}\right)$ according to the equation:

$\mathrm{C}_{f}=M_{\mathrm{x}} / M_{\mathrm{b}}$

where $M_{\mathrm{x}}$ is the mean concentration of a pollutant from at least five samples in the contaminated site and $M_{\mathrm{b}}$ is the pre-industrial concentration of elements using the Earth's crust as a reference value (Loska et al. 2004). Hakanson (1980) has described four categories: $C_{\mathrm{f}}<1$ indicates low contamination, $1 \leq C_{\mathrm{f}}<3$ indicates moderate contamination, $3 \leq C_{\mathrm{f}}<6$ indicates considerable contamination, and $6 \leq C_{\mathrm{f}}$ indicates very high degree of contamination. Figure 2 shows the contamination factors $\left(C_{\mathrm{f}}\right)$ for

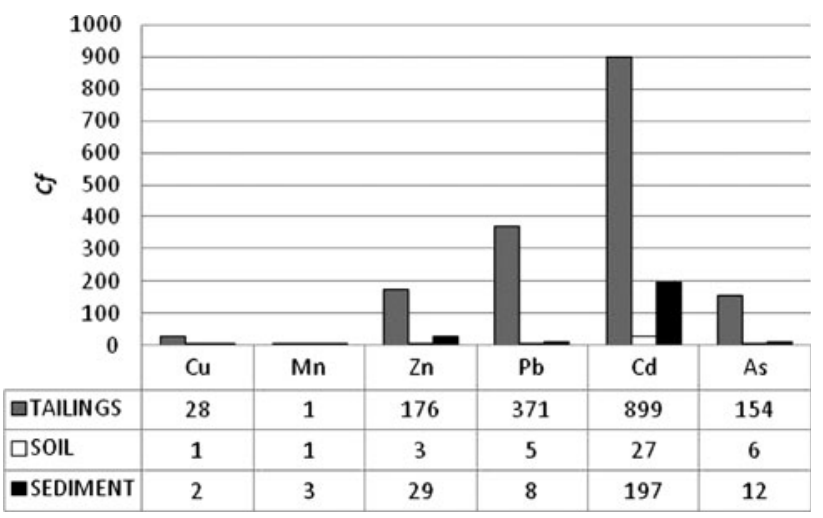

Fig. 2 Contamination factors $\left(C_{\mathrm{f}}\right)$ in mine tailings, agricultural soils and stream sediments from the Kirki mine (NE Greece) individual metals $\mathrm{Cu}, \mathrm{Mn}, \mathrm{Zn}, \mathrm{Pb}, \mathrm{Cd}$ and $\mathrm{As}$ in mine tailings, agricultural soils, and stream sediments. Again cadmium appeared to be the most polluting element. Very high contamination factors were recovered in the mine tailings that were in decreasing order $\mathrm{Pb}>\mathrm{Zn}>\mathrm{As}>\mathrm{Cu}$. Contamination of agricultural soils was moderate for $\mathrm{Cu}$ and $\mathrm{Mn}$, considerable for $\mathrm{Zn}$ and $\mathrm{Pb}$ and very high for $\mathrm{As}$ and $\mathrm{Cd}$. Stream sediments exhibited moderate contamination for $\mathrm{Cu}$ and $\mathrm{Mn}$ and very high contamination for all other elements, which were in decreasing order $\mathrm{Cd}>$ $\mathrm{Zn}>\mathrm{As}>\mathrm{Pb}$.

Hakanson (1980) also proposed the use of a cumulative index defined as the degree of contamination $\left(C_{\mathrm{d}}\right)$, which is calculated by summing all individual contamination factors. Here we have used a modified version of this index, called modified degree of contamination $\left(\mathrm{m} C_{d}\right)$ introduced by Abrahim and Parker (2008). This is calculated by the following equation:

$\mathrm{m} C_{\mathrm{d}}=\frac{\Sigma C_{\mathrm{f}}}{n}$

where $n=$ number of analyzed samples and $C_{\mathrm{f}}=$ contamination factor. This generalized formula allows the incorporation of several metals without the restraint of an upper limit. The modified degree of contamination for tailings, agricultural soil and sediments in this study was $271.3,7.0$ and 41.8, respectively. This is indicative of a "high" degree of contamination for agricultural soils and an "ultra high" degree of contamination for abandoned tailings basins and riverine stream sediments (Abrahim and Parker 2008).

Overall these data show that the natural environment surrounding the "Agios Philippos" mine in the Kirki region (NE Greece) is severely contaminated by heavy metals $(\mathrm{Cd}, \mathrm{Pb}, \mathrm{Zn}, \mathrm{As}$ and $\mathrm{Cu})$. Precautionary actions should be considered in order to prevent the dispersion of pollution and avoid population exposures. Calculating these risks urges for an immediate remediation plan.

Acknowledgments Christos Nikolaidis has been supported by the Greek State Scholarships Foundation (IKY).

\section{References}

Abrahim GMS, Parker RJ (2008) Assessment of heavy metal enrichment factors and the degree of contamination in marine sediments from Tamaki Estuary, Auckland, New Zealand. Environ Monitor Asess 136:227-238

Buat-Menard P, Chesselet R (1979) Variable influence of the atmospheric flux on the trace metal chemistry of oceanic suspended matter. Earth Planet Sci Lett 42:398-411

Chon H-T, Hwang J-H (2000) Geochemical characteristics of the acid mine drainage in the water system in the vicinity of the Dogye coal mine in Korea. Environ Geochem Health 22:155-172 
EU directive 98/83/EC Council Directive on the quality of water intended for human consumption

Hakanson L (1980) Ecological risk index for aquatic pollution control, a sedimentological approach. Water Res 14:975-1001

Loska K, Wiechula D, Korus I (2004) Metal contamination of farming soils affected by industry. Environ Int 30:159-165

Loupasakis C, Konstantopoulou G (2010) Safety assessment of abandoned tailings ponds: an example from Kirki mines, Greece. Bull Eng Geol Environ 69:63-69

Müller G (1969) Index of geoaccumulation in sediments of the Rhine River. Geoj 2:108-118

Olías M, Cerón JC, Fernández I, De la Rosa J (2005) Distribution of rare earth elements in an alluvial aquifer affected by acid mine drainage: the Guadiamar aquifer (SW Spain). Environ Pollut 135:53-64

Stoffers P, Glasby GP, Wilson CJ, Davis KR, Watter P (1986) Heavy metal pollution in Wellington harbour. NZ J Mar Freshwat Res 20:495-512

Sutherland RA (2000) Bed sediment-associated trace metals in an urban stream, Oahu, Hawaii. Environ Geol 39:611-626

Taylor SR, McLennan SM (1995) The geochemical evolution of the continental crust. Rev Geophys 33:241-265

Triantafyllidis S, Skarpelis N, Komnitsas K (2007) Environmental characterization and geochemistry of Kirki, Thrace, NE Greece, abandoned flotation tailing dumps. Environ Forensics 8:351-359 